\title{
ANALISIS BIAYA, PENDAPATAN DAN R/C PADA USAHA PEMBESARAN IKAN LELE DENGAN METODE LONGYAM DI DESA NASOL KECAMATAN CIKONENG KABUPATEN CIAMIS
}

\author{
BANGBANG SUBANGKIT $^{1 *}$, DINI ROCHDIANI ${ }^{2}$, BUDI SETIA ${ }^{1}$ \\ ${ }^{1}$ Fakultas Pertanian, Universitas Galuh \\ ${ }^{2}$ Fakultas Pertanian, Universitas Padjadjaran \\ *Email: subangkit492@gmail.com
}

\begin{abstract}
ABSTRAK
Penelitian ini bertujuan untuk mengetahui : 1) Besarnya biaya, pendapatan dan pendapatan pada usaha pembesaran ikan lele dengan metode longyam di Desa Nasol Kecamatan Cikoneng Kabupaten Ciamis. 2) Besarnya nilai R/C pada usaha pembesaran ikan lele dengan metode longyam di Desa Nasol Kecamatan Cikoneng Kabupaten Ciamis per satu kali proses produksi. Penelitian ini dilakukan di Desa Nasol Kecamatan Cikoneng Kabupaten Ciamis dengan menggunakan Metode Studi Kasus. Dengan mengambil sampel pada seorang pengusaha pembesaran ikan lele dengan metode longyam. Hasil penelitian menunjukan bahwa : 1) Besarnya total biaya produsi pada usaha pembesaran ikan lele dengan metode longyam di Desa Nasol Kecamatan Cikoneng Kabupaten Ciamis sebesar Rp. $8,733,194.02$, per satu kali proses produki, dan besarnya penerimaan dan pendapatan sebesar Rp. 15,462,500 Dan Rp. 6,729,305.96 per satu kali proses prouksi. 2) Besarnya nilai R/C Usaha pembesaran ikan lele dengan metode longyam di Desa Nasol Kecamatan Cikoneng Kabupaten Ciamis sebesar 1,77 per satu kali proses produksi.
\end{abstract}

Kata Kunci : Longyam, R/C, Ikan Lele.

\section{ABSTRACT}

This study aims to find out : 1) The amount of total production costs, amount of revenue and income in catfish enlargement business with longyam method in Nasol Village Cikoneng Sub-District Ciamis District per one-time production process. 2) The amount of $R / C$ value in the catfish enlargement business with longyam method in Nasol Village Cikoneng Sub-District Ciamis District per one- time production process. This research was conducted in Nasol Village, Cikoneng SubDistrict, Ciamis District using Case Study Method. By taking a sample to a catfish enlargement business with longyam method. The results showed that : 1) The amount of total production costs, amount of revenue and income in catfish enlargement business with longyam method in Nasol Village Cikoneng Sub-District Ciamis District per one-time production process was Rp. 8,733,194.02 per onetime production process. And the amount of revenue and income is Rp. 15,462,500 and Rp. $6,729,305.96$ per one-time production process. 2) The amount of the $R / C$ value of catfish enlargement business with longyam method in Nasol Village Cikoneng Sub-District Ciamis District is 1,77 per onetime production process.

Keywords : Longyam, R/C, Catfish.

\section{PENDAHULUAN}

Sektor perairan Indonesia tidak terlepas dari salah satu sumber daya hayati yang terkandung di dalamnya, yaitu sumber daya perikanan. Sektor perikanan Indonesia memiliki potensi produksi yang cukup besar. Hal tersebut karena Indonesia merupakan negara yang memiliki wilayah perairan yang luas. Sehingga sektor perikanan memiliki potensi yang besar untuk dikembangkan. Namun potensi yang besar selama ini belum dimanfaatkan dengan baik, sehingga produksi perikanan 
Indonesia belum mampu mencukupi permintaan ikan domestik maupun luar negeri (Jhon Mondesa Sembiring, 2011).

Ikan lele merupakan salah satu jenis ikan air tawar yang sudah dibudidayakan secara komersial oleh masyarakat Indonesia terutama di Pulau Jawa. Budidaya lele saat ini banyak ditemui di propinsi Jawa Barat dan Jawa Tengah. Jawa Barat merupakan daerah yang memiliki prospek yang cukup baik untuk pengembangan produksi ikan, hal tersebut dikarenakan daerah Jawa Barat memiliki curah hujan yang cukup tinggi sehingga dapat memicu ikan untuk berkembang biak dengan baik. Seperti yang diketahui untuk Jawa Barat, biasanya pembudidayaan perikanan banyak ditemukan di Tasikmalaya, Indramayu, Sukabumi, Bogor dan Ciamis. (Jhon Mondesa Sembiring, 2011).

Menurut BPP Kecamatan Cikoneng (2020), pembudidayaan ikan lele yang umumnya dilakunan di Kecamatan Cikoneng adalah dengan menggunakan kolam tanah, kolam tembok, dan kolam terpal (bioflok), tetapi semakin hari semakin banyak pembudidaya ikan lele yang mengeluh akan tingginya harga pakan, sehingga keuntungan yang didapat semakin berkurang. Harga pakan yang tinggi merupakan permasalahan utama yang dihadapi pembudidaya ikan lele di Kecamatan Cikoneng.

Alternatif pakan lele baru dengan memanfaatkan kotoran hewan ternak memberikan manfaat sehingga peternak lele akan terhindar dari kerugian dan akan mendapatkan pakan lele dengan murah dan gratis. Sehingga metode pembesaran ikan lele yang memanfaatkan limbah kotoran ayam petelur (longyam), menjadi salah satu alternatif pembudidaya dalam pembesaran ikan lele.

\section{Identifikasi Masalah}

Berdasarkan uraian tersebut maka dapat diidentifikasi beberapa masalah sebagai berikut :

1. Berapakah besarnya biaya, penerimaan dan pendapatan pada Usaha Pembesaran Ikan Lele Dengan Pemanfataan Limbah Kotoran Ayam Petelur Di Desa Nasol Kecamatan Cikoneng Kabupaten Ciamis dalam satu kali proses produksi?

2. Berapakah $\mathrm{R} / \mathrm{C}$ pada Usaha Pembesaran Ikan Lele Dengan Pemanfataan Limbah Kotoran Ayam Petelur Di Desa Nasol Kecamatan Cikoneng Kabupaten Ciamis dalam satu kali proses produksi? 
METODE PENELITIAN

\section{Jenis Penelitian}

Jenis penelitian yang akan digunakan adalah studi kasus pada seorang petani pembesaran ikan lele yang memanfaatkan limbah kotoran ayam petelur untuk pakan pembesaran ikan lele yang berlokasi di Desa Nasol Kecamatan Cikoneng Kabupaten Ciamis. Metode studi kasus, menurut Idrus (2009), metode studi kasus lebih mirip dengan metode survei. Bedanya dalam studi kasus, populasi yang diteliti lebih terarah dan terfokus pada sifat tertentu yang tidak berlaku umum. Biasanya dibatasi oleh kasus, lokasi, tempat, serta waktu tertentu.

\section{Operasionalisisi Variabel}

Variabel-variabel yang akan digunakan dalam penelitian ini adalah sebagai berikut :

1. Satu kali proses produksi dimulai dari penyediaan benih, persiapan kolam, perawatan, sampai lele di panen. Selama satu kali proses produksi (3 bulan).

2. Biaya produksi adalah nilai dari semua pengeluaran yang dikeluarkan oleh pelaku pembesaran ikan lele dengan metode longyam terdiri dari:

- Biaya Tetap (fixed cost) adalah biaya yang jumlah totalnya akan sama dan tetap tidak berubah sedikitpun walaupun jumlah barang yang diproduksi dan dijual berubah ubah dalam kapasitas normal. Biaya tetap tidak berubah dengan peningkatan atau penurunan jumlah barang ataupun jasa yang dihasilkan. Biaya tetap adalah biaya yang harus dibayar oleh perusahaan terlepas dari akivitas bisnis terdiri dari :

a. Pajak bumi dan bangunan, yaitu biaya yang dikeluarkan untuk membayar pajak bumi dan bangunan dalam satu kali proses produksi dihitung dalam satuan rupiah (Rp) per satu kali proses produksi.

b. Bunga modal tetap yaitu biaya yang dihitung berdasarkan bunga bank yang berlaku pada saat penelitian dan dinilai dalam satuan rupiah ( $R p)$ per satu kali proses produksi.

c. Penyusutan alat dan bangunan, di hitung dalam satuan rupiah selama satu kali proses produksi. Untuk mengetahui perhitungan penyusutan alat dan bangunan menggunakan metode garis lurus (straight line method), dengan menggunakan rumus: 
Penyusutan $=\frac{\text { Nilai Beli }- \text { Nilai Sisa }}{\text { Umur Ekonomis }}$

Nilai sisa adalah nilai pada waktu alat itu sudah tidak dapat digunkan lagi atau dianggap nol.

3. Biaya Variabel (Variable Cost) adalah biaya yang besar kecilnya dipengaruhi oleh besar kecilnya produksi dan sifatnya habis dalam satu kali produksi:

a. Bibit adalah jumlah pemakaian bibit ikan lele yang digunakan dalam satu kali musim produksi, diukur dalam satuan ekor. Biaya bibit dihitung berdasarkan besarnya biaya yang dikeluarkan untuk membeli bibit ikan lele dalam per satu kali proses produksi.

b. Pakan limbah adalah jumlah limbah kotoran ayam petelur yang digunakan dalam satu kali proses produksi, diukur dalam satuan kilogram (kg), Biaya pakan limbah dihitung berdasarkan biaya yang dikeluarkan untuk memperoleh pakan limbah dalam satu kali proses produksi, diukur dalam satuan rupiah per satu kali pross produksi.

c. Obat-obatan adalah jumlah pemakaian obat-obatan yang digunakan dalam proses produksi selama satu kali proses produksi, diukur dalam satuan mili liter (ml). Biaya obat-obatan dihitung berdasarkan besarnya biaya yang dikeluarkan untuk membeli obatobatan dalam satu kali proses produksi, diukur dalam satuan rupiah per satu kali proses produksi.

d. Vitamin adalah jumlah pemakaian vitamin yang digunakan dalam proses produksi selama satu kali musim produksi, diukur dalam satuan mili liter (ml). Biaya vitamin dihitung berdasarkan besarnya biaya yang dikeluarkan untuk membeli vitamin dalam satu kali proses produksi, diukur dalam satuan rupiah per satu kaliproses produksi.

e. Bunga modal variabel yaitu biaya yang dihitung berdasarkan bunga bank yang berlaku pada saat penelitian dan dinilai dalam satuan rupiah (Rp) per satu kali proses produksi

f. Tenaga kerja adalah banyaknya orang yang berkerja selama satu kali proses produksi. Penggunaan tenaga kerja diukur dalam satuan 
hari orang kerja (HOK). besarnya biaya untuk HOK diukur dalam satuan rupiah per satu kali proses produksi.

4. Penerimaan adalah perkalian antara jumlah produk dengan harga dihitung dalam satuan rupiah, dalam satu kali proses produksi.

5. Pendapatan adalah selisih antara penerimaan total dengan biaya total dinyatan kedalam satuan rupiah, dalam satu kali proses produksi.

6. R/C (Revenue Cost Ratio) yaitu ukuran perbandingan antara penerimaan usaha (Total Revenue $=$ TR) dengan total biaya (Total Cost $=$ TC) dengan nilai $\mathrm{R} / \mathrm{C}$, dapat diketahui apakah suatu usaha mengunungkan atau tidak menguntungkan. Usaha efisien (menguntungkan) jika R/C >1.

Dimana :

a. $\mathrm{R} / \mathrm{C}<1$, maka usaha tersebut rugi sehingga tidak layak diteruskan.

b. $\mathrm{R} / \mathrm{C}=1$, maka usaha tersebut tidak untung tidak rugi (impas) sehingga tidak layak diteruskan.

c. R/C >1, maka usaha tersebut untung sehingga layak diteruskan.

Dengan asumsi:

a. Harga input maupun output adalah harga yang berlaku pada saat penelitian. b. Barang habis terjual.

\section{Teknik Pengumpulan Data}

Data yang akan digunakan dalam penelitian berupa data primer yang diperoleh melalui wawancara langsung kepada responden dan data sekunder yang diperoleh dari dinas maupun intansi yang berkaitan dengan penelitian. .

\section{Teknik Penarikan Sampel}

Teknik penarikan sampel dilakukan dengan metode purposive sampling yaitu pengambilan sampel secara sengaja, dengan pertimbangan bahwa berdasarkan data BPP Kecamatan Cikoneng tahun 2019 hanya terdapat satu orang pembudidaya pembesaran ikan lele yang memanfaatkan limbah kotoran ayam petelur di Desa Nasol Kecamatan Cikoneng Kabupaten Ciamis. Dimana Kecamatan Cikoneng sebagai salah satu sub-sentra pembudidaya ikan lele yang produktivitasnya di atas rata-rata Kabupaten Ciamis.

\section{Rencana Analisis Data}

Data yang diperoleh akan dianalisis dengan menggunakan metode deskriptif kuantitatif. untuk mengetahui biaya produksi, penerimaan, pendapatan, dan $\mathrm{R} / \mathrm{C}$ dianalisis menggunakan rumus sebagai berikut :

1. Analisis Biaya

Menurut Rodjak (2006), untuk mengitung besarnya biaya total (total 
cost) diperoleh dengan menjumlahkan biaya tetap (fixed cost) dengan biaya variabel (variable cost), dan dihitung dengan rumus :

$\mathbf{T C}=\mathbf{F C}+\mathrm{VC}$

Dimana :

TF $\quad=$ Total Cost $($ Biaya Total $)$

FC = Fixed Cost (Biaya Tetap

Total)

VC = Variable Cost (Biaya

Varibel Total)

2. Analisis Penerimaan

Menurut Suratiyah (2006), secara umum perhitungan penerimaan total (total revenue) adalah perkalian antara jumlah produksi dengan harga jual dan dihitung dengan rumus sebagai berikut ;

\section{TR = Y x Py}

Dimana :

$\mathrm{TR}=$ Total Revenue

(Penerimaan Total)

$\mathrm{Y}=$ = Produksi Yang Diperoleh

Py = = Harga

3. Analisis Pendapatan

Menurut Suratiyah (2006), pendapatan adalah selisih antara penerimaan dengan biaya total, dan dapat dihiung dengan rumus sebagai berikut :

$\mathbf{p d}=\mathbf{T R}-\mathbf{T C}$

dimana

$\mathrm{pd} \quad=$ Pendapatan
$\mathrm{TR}=$ Total Revenue

(Penerimaan Total)

$\mathrm{TC}=$ Total Cost $($ Biaya Total $)$

4. $\mathrm{R} / \mathrm{C}$

Menurut Rodjak (2006), R/C adalah perbandingan antara penerimaan dengan biaya, dan dihitung dengan rumus :

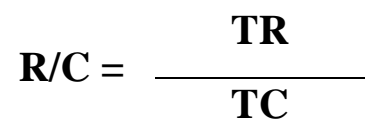

Dimana :

d. $\mathrm{R} / \mathrm{C}<1$, maka usaha tersebut rugi sehingga tidak layak diteruskan.

e. $\mathrm{R} / \mathrm{C}=1$, maka usaha tersebut tidak untung tidak rugi (impas) sehingga tidak layak diteruskan.

f. R/C >1, maka usaha tersebut untung sehingga layak diteruskan.

\section{Tempat dan Waktu Penelitian}

Penelitian ini akan dilaksanakan di Desa Nasol Kecamatan Cikoneng Kebupaten Ciamis. pada penelitian ini dilaksanakan melalui beberapa tahap kegiatan sebagai berikut:

1. Survei pendahuluan dan penulisan usulan penelitian dilaksanakan pada bulan Januari 2020.

2. Kegiatan di lapangan untuk pengumpulan data, direncanakan pada bulan Februari - April 2020.

3. Pengolahan data dan pembuatan laporan hasil penelitian, 
direncanakan pada April 2020 sampai dengan selesai.

\section{HASIL DAN PEMBAHASAN}

\section{Identitas Responden}

Data yang digunakan untuk memberi gambaran umum mengenai identitas responden meliputi umur, pendidikan, pengalaman berusaha dan jumlah tanggungan keluarga.

\section{Umur Responden}

Umur merupakan suatu faktor yang dapat berpegaruh bagi seseorang dalam bekerja, semakin tua umur seseorang maka kemampuan fisik daam bekerja semakin berkurang. Bapak Ade Ramdan yang dijadikan responden dalam peneltian ini berumur 31 tahun.

\section{Tingkat Pendidikan Responden}

Tingkat pendidikan mempunyai peranan yang cukup besar terhadap seseorang dalam kegiatan usahanya, karena tingkat pendidikan dapat mempengaruhi seseorang dalam menerima dan melaksanakan hal-hal baru. Responden sendiri tingkat pendidikan formalnya adalah tamatan Sekolah menengah pertama (SMP).

\section{Tanggungan Keluarga Responden}

Tanggungan keluarga merupakan salah satu factor yang sangat erat kaitannya dengan kemampuan responden dalam mengelola usahanya. Semakin banyak jumlah tanggungan keluarga yang harus dipikul akan semakin termotivasi dalam melaksanakan usahanya, dengan harapan pendapatan yang diperolehnya dapat mencukupi kebutuhan hidup keluarganya. Tanggungan keluarga yang dimaksud dalam penelitian ini adalah jumlah anggota keluarga responden yang masih menjadi tanggung jawab responden dalam memenuhi kebutuhan hidupnya. Berdasarkan hasil wawancara diketahui jumlah tnggungan keluarga responden adalah 5 orang.

\section{Pengalaman Responden Dalam Usaha} Pembesaran Ikan Lele Dengan Metode

\section{Longyam}

Pengalaman berusaha merupakan salah satu faktor menentukan keberhasilan dalam usaha pembesaran ikan lele dengan metode longyam. Semakin lama pengalaman usaha yang dimiliki maka semakin tinggi keterampilan yang dimiliki dalam melakukan proses budidaya, yaitu dengan mempelajari pengalaman yang dialami sehingga semakin mampu dalam menghadapi masalah dan kesulitan yang mana terjadi dalam usaha pembesaran ikan lele, sehingga dapat mentukan solusi terbaik dalam masalah yang dihadapi dalam proses pembesaran ikan lele dengan metode longyam. Pengalam bapak Ade Ramdan dalam melakukan budidya ikan 
lele dengan metode longyam adalah 5 tahun. Itu arinya bapak ade ramdan sudah cukup berpengalan dalam menjalankan usahanya.

Tabel 1. biaya pada Usaha pembesaran ikan lele dengan metode longyam per satu kali proses produksi

\begin{tabular}{lcc}
\hline Komponen Biaya & Jumlah (Rp) & Persentase (\%) \\
\hline A. Biaya Tetap & 7,225 & 0,1 \\
- Pbb & $589,166.67$ & 6,7 \\
- Penyusutan Alat & $10,436.86$ & 0.1 \\
- Bunga Modal Tetap & & \\
& & \\
Jumlah & $\mathbf{6 0 6 , 8 2 8 . 5 2}$ & \\
B. Biaya Variabel & $3,790,000$ & 43,4 \\
- Bibit & 10,000 & 0,1 \\
- Garam Korosok & 540,000 & 6,2 \\
- Viamin & 210,000 & 2,4 \\
- Obat Obatan & $1,881,600$ & 21,5 \\
- Pakan Limbah & $1,555,000$ & 17,8 \\
- Tenaga Kerja & $139,765.50$ & 1.6 \\
- Bunga Modal Variabel & & \\
Jumlah & $\mathbf{8 , 1 2 6 , 3 6 5 . 5 0}$ & $\mathbf{1 0 0}$ \\
\hline
\end{tabular}

Sumber : Data Primer

Tabel 1 menunjukan bahwa biaya total pada usah pembesaran ikan lele dengan metode longyam dalam satu kali proses produksi adalah Rp. 8,733,194.02, yang terdiri dari biaya tetap sebesar 606,828.52, dan biaya variabel sebesar $8,126,365.50$ per satu kali proses produksi.

\section{Analisis Penerimaan}

Penerimaan adalah perkalan antara jumlah produksi dengan harga jual produk. Harga jual ikan lele yang diperoleh adalah sebesar Rp. 12.500/kg. sedangkan hasil dari pembesarandalam satu kali proses produksi adalah sebesar $1.237 \mathrm{~kg}$ ikan lele.
Jadi penerimaan yang diperoleh adalah Rp. $15,462,500$.

\section{Analisis Pendapatan}

Pendapatan atau keuntungan adalah selisih antara penerimaandengan biaya total. Total biaya yang dikeluarkan adalah sebesar Rp. 8,733,194.02dan total penerimaan adalah sebesar Rp. 15,462,500. Sehingga didapat keuntungan adalah sebesar Rp.6,729,305.96.

\section{Analisis R/C}

$\mathrm{R} / \mathrm{C}$ adalah perbandinan antara penerimaaan dengan biaya. Jadi penerimaan yang diterima oleh bapak Ade 
Ramdan dalam satu kali proses produksi adalah sebesar Rp. 15,462,500. dan biaya yang dikeluarkan adalah sebesar Rp. $8,733,194.02$. sehingga di dapat R/C pada usaha pembesaran ikan lele dengan metode longyam dalam satu kali proses produksi sebesar 1,77. Artinya setiap biaya yang dikeluarkan Rp. 1 akan diperoleh penerimaan Rp. 1,77 dan pendapatan sebesar Rp. 0,77. oleh karena itu usaha pembesaran ikan lele dengan metode longyam menguntungkan dan layak untuk diusahakan.

\section{KESIMPULAN DAN SARAN}

\section{Kesimpulan}

Berdasarkan hasilpeneltian dan pembahasan dapat dapat diambil kesimpulan sebagai berikut :

1. Besarnya biaya total produksi pada usaha pembesaran ikan lele dengan metode longyam di Desa Nasol Kecamatan Cikoneng Kabupaten Ciamis dalam satu kali proses produksi adalah Rp. 8,733,194.02, besarnya penerimaan dan pendapatan pada usaha pembesaran ikan lele dengan metode longyam dalam satu kali proses produksi adalah sebesar Rp. 15,462,500 dan Rp.6,729,305.96.
2. Berdasarkan nilai $\mathrm{R} / \mathrm{C}$ pada usaha pembesaran ikan lele dengan metode longyam dalam di Desa Nasol Kecamatan Cikoneng Kabupaten Ciamis satu kali proses produksi adalah sebesar 1.77.

\section{Saran}

Berdasarkan kesimpulan penelitian, maka diajukansaran sebagi berikut :

1. Pembudidaya ikan lele dengan metode longyam hendakya melanjutkan usahanya karena usaha tersebut mengunungkan. Dan perlunya peningkatan skala budidya sehingga akan terjadi peningkatan pendapatan bagi pengelola usaha.

2. Harus dilakukan pencatatan perusahaan baik itu pencatatan biaya, penjualan, penerimaan dan pendapatan.

\section{DAFAR PUSTAKA}

Ajeng, T. C. 2014. Analisis Usaha Terpadu Pada Anugrah Farm Di Kecamatan Tajur Halang Kabupaten Bogor. Institut Pertanian Bogor 2014.

Balai Penyuluh Pertanian Kecamatan Cikoneng Interview. Profil Budidaya Ikan Lele Kecamatan Cikoneng Tahun 2019. Cikoneng.

Danang Kurniawan. 2013. Kajian tingkat Kesejahteraan Keluarga Pembudidaya Ikan Lele Di Desa Purwonegoro Kecamatan Purwanegara Kabupaten Banjarnegara. Universitas Muhammadiah Purwokerto 2013. 
Dinas Peternakan dan Perikanan Kabupaten Ciamis. Data Produksi Ikan Kabupaten Ciamis Tahun 2019, Ciamis : Dinas Peternakan dan Perikanan Kabupaten Ciamis

Friska, M. A. 2012. Analisis Usahatani Pembesaran Ikan Mas Di Kabupaten Sragen. Universitas Sebelas Maret.

Hendriana, A. 2010. Pembesaran Ikan Lele Di Kolam Terpal. Yogyakarta. Lily Publisher.

Idrus. 2006. Analisis Biaya, Pendapatan, Dan R/C Agroindustri Gula Kelapa (Studi Kasus Di Desa Kedung Wuluh Kecamatan Padaherang Kabupaten Pangandaran). Universitas Galuh 2017.

Jhon, M. S. 2011. Analisis Kelayakan Usaha Pembesaran Ikan Lele Sangkuriang (Clarias sp) (Studi
Kasus : Yoyok Fish Farm, Desa Pasir Angin, Kecamatan Mega Mendung, Bogor, Jawa Barat. Institut Pertanian Bogor 2011.

Kasmir. 2009. Analisis Laporan Keuangan Edisi 1. Jakarta. Rajawali Pers

Khairuman dan K Amri. 2013. Budidaya Lele Dumbo Secara Intensif. Jakarta:Agro Media Pustaka.

Rodjak, A. 2006. Manajemen Usahatani. Pustaka Gratuna. Bandung.

Suratiah. 2006. Ilmu Usaha Tani. Penebar Swadaya. Jakarta.

Wiwit Rahayu. 2011. Analisis pendapatan Usaha Pembesaran Ikan Nila Merah (Oreochromis sp.) Pada Kolam Air Deras di Kecamatan Polanharjo Kabupaten Klaten. Universitas Sebelas Maret 2011. 